\title{
Achieving the Carbon-Neutral Production of Magnesia and Silica Products Using a $\mathrm{HCl}$-Based Process in Serpentine Feedstock ${ }^{+}$
}

\author{
David Konlechner ${ }^{1, *(1)}$ and Gregor Kappacher ${ }^{2}$ \\ 1 KON Chemical Solutions e.U., 1020 Vienna, Austria \\ 2 Tenova Branch Office Austria, 1110 Vienna, Austria; gregor.kappacher@tenova.com \\ * Correspondence: david.konlechner@kon-chem.com; Tel.: +43-699-11-77-99-33 \\ + Presented at International Conference on Raw Materials and Circular Economy, Athens, Greece, \\ 5-9 September 2021.
}

check for

updates

Citation: Konlechner, D.; Kappacher, G. Achieving the Carbon-Neutral Production of Magnesia and Silica Products Using a HCl-Based Process in Serpentine Feedstock. Mater. Proc. 2021, 5, 19. https://doi.org/ 10.3390/materproc2021005019

Academic Editor: Anthimos Xenidis

Published: 18 November 2021

Publisher's Note: MDPI stays neutral with regard to jurisdictional claims in published maps and institutional affiliations.

Copyright: (C) 2021 by the authors. Licensee MDPI, Basel, Switzerland. This article is an open access article distributed under the terms and conditions of the Creative Commons Attribution (CC BY) license (https:// creativecommons.org/licenses/by/ $4.0 /)$.

\begin{abstract}
Magnesia is mainly produced from carbonate sources (magnesite $\left(\mathrm{MgCO}_{3}\right)$ ), and seawater brines $\left(\mathrm{MgCl}_{2}\right)$. The calcination of magnesite and the precipitation of brine using quicklime $(\mathrm{CaO})$ are processes that have significant $\mathrm{CO}_{2}$ footprints, even before considering the burning of hydrocarbons required to meet the energy demand. There are also significant amounts of silica-based magnesia raw materials available worldwide, such as serpentine, dunite, and olivine. It is possible to produce synthetic $\mathrm{MgO}$ of high purity using a $\mathrm{HCl}$-based process. $\mathrm{HCl}$ can be fully recycled and reused. If a carbon-neutral heating source such as electricity, synthetic fuel, or plasma is used for the pyrohydrolysis process, the result is the production of $\mathrm{MgO}$ via a carbon-neutral process.
\end{abstract}

Keywords: $\mathrm{HCl}$ process; serpentine; magnesia; silica; zero waste; carbon neutral

\section{Introduction}

At present, the main mineral source for $\mathrm{MgO}$ and $\mathrm{Mg}(\mathrm{OH})_{2}$ products is $\mathrm{MgCO}_{3}$. The evaluation of molar masses shows that the production of one ton of $\mathrm{MgO}$ from $\mathrm{MgCO}_{3}$ directly results in the release of 1.09 tons of $\mathrm{CO}_{2}$ into the atmosphere, not counting the $\mathrm{CO}_{2}$ released due to process heating. If $\mathrm{MgO}$ is produced from silicate sources, the liberation of carbonate-fixed $\mathrm{CO}_{2}$ can be avoided.

This paper presents a $\mathrm{HCl}$-based zero-waste process route for serpentine ores that will produce $\mathrm{SiO}_{2}$, water glass, precipitated silica, $\mathrm{MgO}$, high-purity $\mathrm{MgO}, \mathrm{Mg}(\mathrm{OH})_{2}$, and an iron hydroxide fraction under carbon-neutral conditions.

The process starts with a $\mathrm{HCl}$ leaching stage, where the dissolvable components, such as $\mathrm{Mg}$ and $\mathrm{Fe}$, are separated from the non-dissolvable silica fraction.

The silica generated can be mechanically upgraded to a basic-grade silica fraction. Alternatively, a caustic leaching procedure can be employed, using $\mathrm{NaOH}$ to dissolve the amorphous $\mathrm{SiO}_{2}$ component and generate water glass with a high ratio of silica to sodium. An additional acid treatment will convert the water glass to precipitated silica.

The liquid phase that results after the $\mathrm{HCl}$ leaching process is purified by the adjustment of the $\mathrm{pH}$. Iron and other elements precipitate as hydroxides, leaving a pure $\mathrm{MgCl}_{2}$ solution. The filter cake, which mainly consists of iron hydroxides, can be used as a source of iron for a steel mill.

The pure $\mathrm{MgCl}_{2}$ solution undergoes a spray roasting process that produces technicalgrade $\mathrm{MgO}$ as well as $\mathrm{HCl}$ (which can be reused in the leaching process), as per the following equation:

$$
\mathrm{MgCl}_{2}+\mathrm{H}_{2} \mathrm{O} \stackrel{\sim 500}{\rightarrow}{ }^{\circ} \mathrm{C} \mathrm{MgO}+2 \mathrm{HCl},
$$


Highly purified caustic calcined magnesia (CCM) can be produced if the technicalgrade $\mathrm{MgO}$ is further washed and calcined. Alternatively, a hydration procedure can be applied to produce $\mathrm{Mg}(\mathrm{OH})_{2}$ at different, market-specific quality levels.

Looking at the entire process as a whole, it can be stated that spray roasting is the second-largest producer of $\mathrm{CO}_{2}$. If new, non-carbon-emitting energy sources can be used in this stage, such as direct electrical heating or hydrogen burner systems, this would represent a significant step toward the $\mathrm{CO}_{2}$-free production of $\mathrm{MgO}$.

Figure 1 shows a block flow diagram of the described $\mathrm{MgO}$ production process, where serpentine is used as a feedstock.

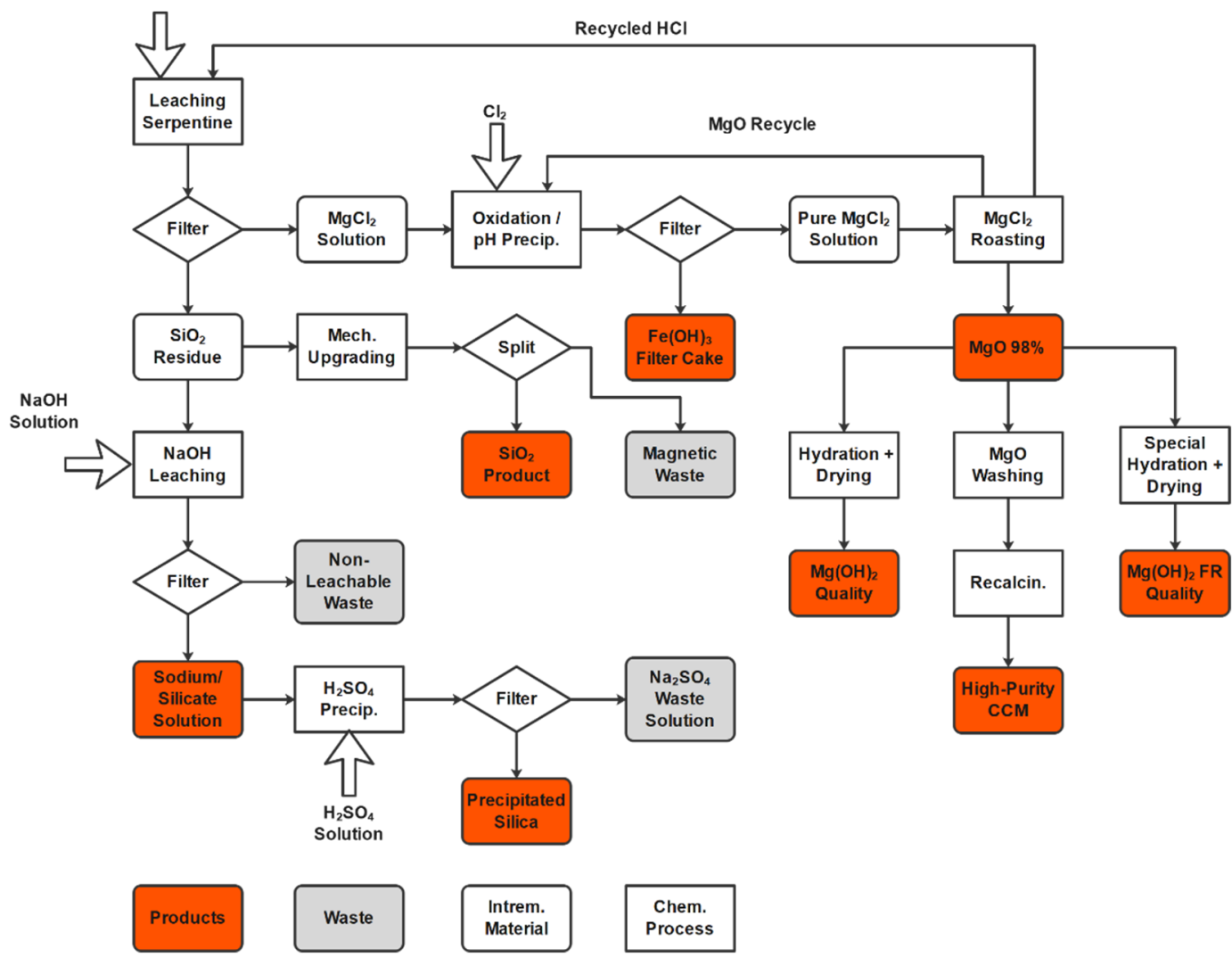

Figure 1. $\mathrm{MgO}$ production process using serpentine as a raw material.

\section{Materials and Methods}

\subsection{Industrial Style Process Flow Diagram}

A commercial application of the conceptual carbon-neutral process is shown in the process flow diagram (PFD) in Figure 2. The process comprises unit operations currently offered by KON Chemical Solutions and Tenova and incorporates public-domain knowledge gained from decades of process development [1-4]. It includes the commercially established unit operation for producing high-quality synthetic magnesium oxide $(\mathrm{MgO})$. If the process includes a carbon-neutral heating system, it will constitute the first industrialscale carbon-neutral process for the production of $\mathrm{MgO}$. There is also the potential for the minimization of waste by commercializing by-products such as silica [5]. The process for this is described below. 


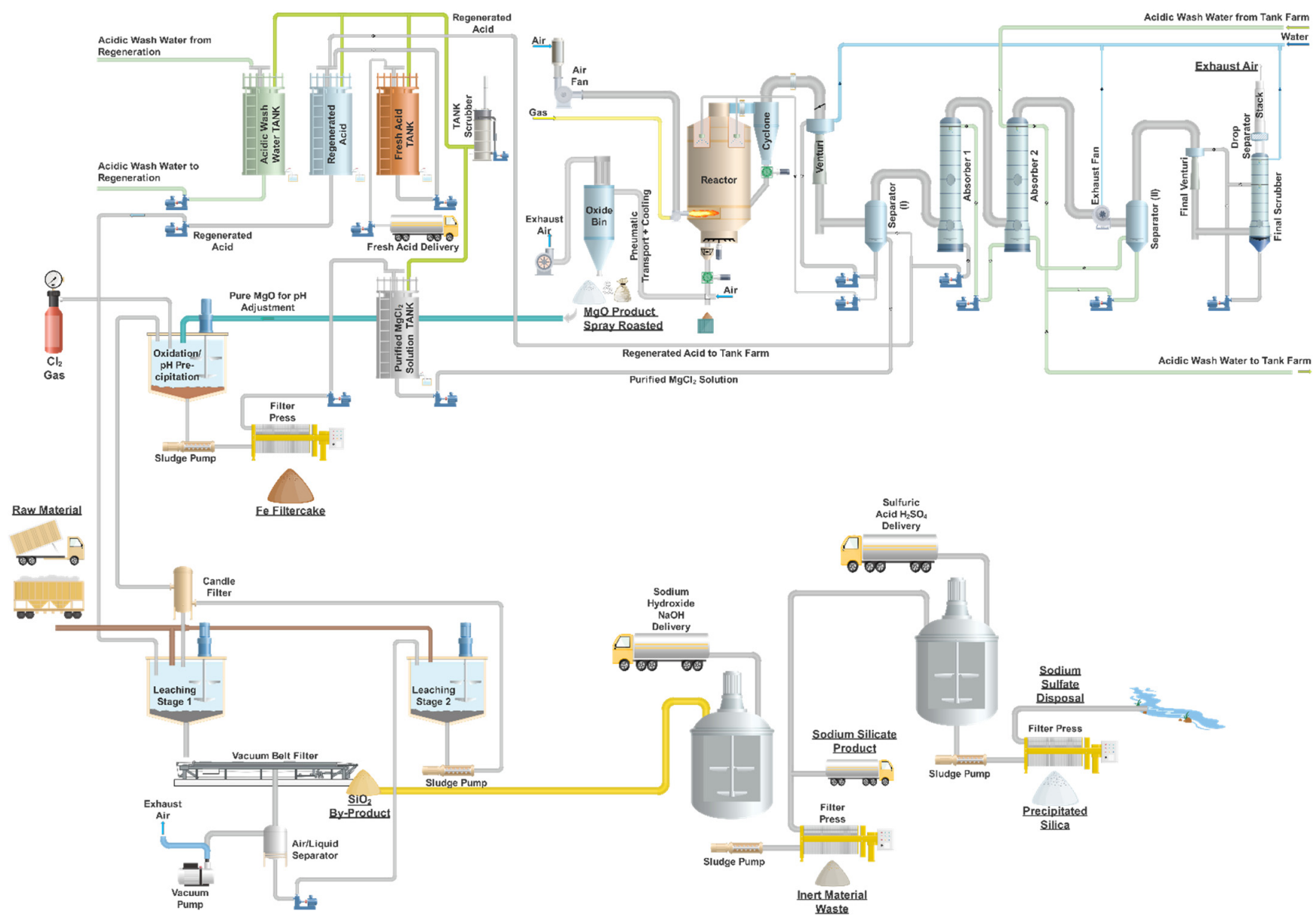

Figure 2. Industrial-style PFD showing the key process equipment used.

\subsubsection{Leaching}

In the leaching section, the raw material (serpentine) is brought into contact with regenerated acid at a temperature of about $80^{\circ} \mathrm{C}$ and a $\mathrm{HCl}$ strength of about $18 \% \mathrm{~m} / \mathrm{m}$. The leaching operation has two stages, with the first stage controlled to a specific amount of excess $\mathrm{HCl}$ to maximize the leaching efficiency of the raw material. The undissolved fraction, mainly silica, is separated by a filtration step and the liquid part, containing $\mathrm{MgCl}_{2}$ and other dissolvable elements, is transferred to the second leaching stage. In this step, an additional amount of fine raw material is added to consume the free $\mathrm{HCl}$. The slurry is now brought to a second filter stage, where the solid fraction is separated and put back to the first leaching stage to finalize the leaching procedure. The liquid phase is transferred to the next unit of the operation for oxidation and precipitation.

\subsubsection{Oxidation and Precipitation}

The impure $\mathrm{MgCl}_{2}$ solution gained from leaching is purified by oxidation and precipitation. Firstly, $\mathrm{Cl}_{2}$ gas is used to oxidize the $\mathrm{Fe}^{2+}$ in the solution to $\mathrm{Fe}^{3+}$ according to Equation (2).

$$
2 \mathrm{FeCl}_{2}+\mathrm{Cl}_{2} \rightarrow 2 \mathrm{FeCl}_{3} \text {. }
$$

Pure $\mathrm{MgO}$ originating from further down the process is then used to raise the $\mathrm{pH}$ value of the solution and precipitate $\mathrm{Fe}, \mathrm{Ni}$, and $\mathrm{Al}$ as hydroxides. The hydroxides are removed via filtration, while $\mathrm{MgCl}_{2}$ and $\mathrm{CaCl}_{2}$ remain as chlorides in dissolved form. 


\subsubsection{Tank Farm}

The tank farm is a buffer unit that creates separation between single process steps at an industrial scale. Buffer volumes are important to the maintenance of continuous operation and ensure that a small interruption at a single unit will not stop the whole plant.

\subsection{4. $\mathrm{MgO}$ Roasting and $\mathrm{HCl}$ Recovery}

Roasting is the heart of the process. Purified $\mathrm{MgCl}_{2}$ solution is added to a venturi circuit where the preconcentration of the solution and the cooling of the hot roast gases take place. The concentrated and purified solution is then sprayed into the reactor, where it is transformed into solid $\mathrm{MgO}$ and gaseous $\mathrm{HCl}$. The $\mathrm{MgO}$ falls to the bottom of the reactor, where it is extracted as a primary product. The hot gaseous $\mathrm{HCl}$ leaves the reactor out of the top. It is cleaned, quenched, and finally absorbed in water to generate an aqueous acid that is recycled back to the leaching unit operation.

The groundbreaking new approach within this conceptual process is the use of a carbon-neutral heating source to achieve carbon-neutral production. A flame temperature of more than $1300^{\circ} \mathrm{C}$ provides the energy input required to run the system at reasonable volume flows. Natural gas heating is depicted in Figure 2. This can be replaced by a carbon-neutral system, such as hydrogen burners or plasma. In the mass and energy balance model considered later in this article, plasma is used to heat air to $1300{ }^{\circ} \mathrm{C}$ to facilitate the roasting process.

\subsubsection{Silica Treatment}

As serpentine has a high silica content, the commercialization of this component is important in the development of a sustainable commercial approach to the production of magnesia. The filter cake generated at the leaching stage can be treated with sodium hydroxide to produce a water glass solution. Depending on the specific raw material used, it could be sufficient to use mild leaching conditions below $100{ }^{\circ} \mathrm{C}$ and an ambient pressure. The non-dissolved solid fraction can be separated from the pure water glass, which can then be sold as a product. Alternatively, a second processing step can be introduced, using $\mathrm{H}_{2} \mathrm{SO}_{4}$ or $\mathrm{CO}_{2}$ to convert the water glass to precipitated silica. The production of a salable silica by-product would make $\mathrm{MgO}$ production a near-zero waste process.

\subsection{Mass and Energy Balance}

A mass and energy balance model of the process from raw material leaching to $\mathrm{MgO}$ roasting was built using the Outotec HSC software. The output from the model is summarized in Figure 3.

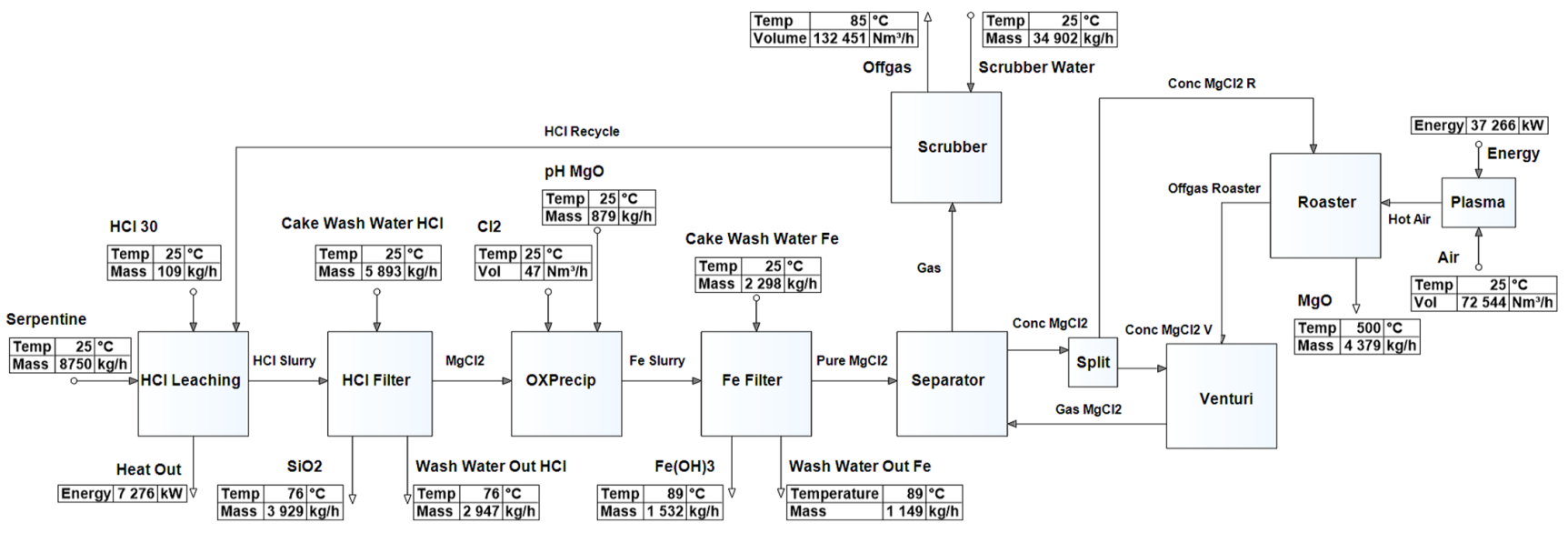

Figure 3. Preliminary mass and energy balance summarizing the input and output streams from leaching to roasting. 
The assumed $8.75 \mathrm{t} / \mathrm{h}$ of raw material input leads to an annual plant capacity of 70,000 $\mathrm{t}$ material input and a theoretical $\mathrm{MgO}$ production of $28,000 \mathrm{t} \mathrm{MgO}$ ( $\mathrm{MgO}$ roasted- $\mathrm{pH} \mathrm{MgO}$ ) for 8000 operation hours.

\section{Results}

West High Yield (WHY) Resources Ltd., a company in Calgary, Alberta, Canada, that engages in the acquisition, exploration, and development of mineral resource properties is currently developing a magnesia project using serpentine material extracted from their Record Ridge mine. The chemical composition of the serpentine is summarized in Table 1. This composition was also considered in the mass and energy balance model shown in Figure 3.

Table 1. Typical chemical analysis of a serpentine sample from the Record Ridge mine.

\begin{tabular}{cccc}
\hline Element & Fraction $\% \mathbf{m} / \mathbf{m}$ & Oxide & Fraction $\% \mathbf{m} / \mathbf{m}$ \\
\hline $\mathrm{Mg}$ & 24.0 & $\mathrm{MgO}$ & 39.8 \\
$\mathrm{Si}$ & 21.0 & $\mathrm{SiO}_{2}$ & 44.9 \\
$\mathrm{Fe}$ & 7.9 & $\mathrm{Fe}_{2} \mathrm{O}_{3}$ & 11.3 \\
$\mathrm{Ca}$ & 0.3 & $\mathrm{CaO}$ & 0.4 \\
$\mathrm{Cr}$ & 0.3 & $\mathrm{Cr}_{2} \mathrm{O}_{3}$ & 0.4 \\
$\mathrm{Al}$ & 0.3 & $\mathrm{Al}_{2} \mathrm{O}_{3}$ & 0.6 \\
$\mathrm{Ni}$ & 0.3 & $\mathrm{NiO}$ & 0.4 \\
$\mathrm{~K}$ & 0.1 & $\mathrm{~K}_{2} \mathrm{O}$ & 0.1 \\
$\mathrm{Rest}$ & 45.8 & & 2.1 \\
Sum & 100.0 & & 100.0 \\
\hline
\end{tabular}

Preliminary tests were carried out at Kingston Process Metallurgy Inc. (KPM), located in Kingston, Ontario, Canada, to evaluate the basic material behavior at the kilogram scale. The test program was engineered to generate fundamental chemical data for the proposed process concept.

The $\mathrm{HCl}$ leaching was carried out at moderate temperatures at an ambient pressure using $18 \% \mathrm{~m} / \mathrm{m}$ of $\mathrm{HCl}$ Solution. Repeat testing led to an average $\mathrm{Mg}$ recovery rate of $91.7 \% \mathrm{~m} / \mathrm{m}$.

The oxidation step was executed with $\mathrm{Cl}_{2}$ gas and the $\mathrm{Fe}^{2+}$ concentration was reduced from a starting point of $4.8 \mathrm{~g} / \mathrm{L}$ down to $0.1 \mathrm{~g} / \mathrm{L}$.

Using $\mathrm{MgO}$ for the $\mathrm{pH}$ adjustment and subsequent filtration of the precipitated hydroxides, it was possible to generate a $\mathrm{MgCl}_{2}$ solution with a purity of $98.9 \% \mathrm{~m} / \mathrm{m}$, with the main contaminant being Ca.

The purified solution was then thermally treated to generate a solid particulate $\mathrm{MgO}$ of technical-grade purity (i.e., $>98 \% \mathrm{~m} / \mathrm{m}$ ).

The technical-grade $\mathrm{MgO}$ was then washed and recalcined to produce a high-purity $(99.87 \% \mathrm{~m} / \mathrm{m}) \mathrm{MgO}$, equivalent to high-purity caustic calcined $\mathrm{MgO}$ (CCM).

Preliminary $\mathrm{NaOH}$ leaching and $\mathrm{H}_{2} \mathrm{SO}_{4}$ precipitation tests were also conducted on the silica leach residue. A reasonable leach efficiency of $82 \% \mathrm{~m} / \mathrm{m}$ was achieved under mild leaching conditions and the precipitated silica product had a purity of $99.5 \% \mathrm{~m} / \mathrm{m} \mathrm{SiO}_{2}$.

\section{Discussion}

This paper presents a process route using non-carbonate magnesium ores for the production of synthetic $\mathrm{MgO}$. The process includes treatment options that commercialize the silica component of the ore. With the use of carbon-neutral heating, the process opens the door to a novel means of $\mathrm{MgO}$ production with a lower ecological footprint.

Building on the successful test work conducted at KPM, a pilot-scale demonstration is the logical next step in the development of the process ahead of commercialization. Key parts of the process have already been demonstrated at a commercial scale. In 2012, Tenova built an industrial-scale pilot plant for the $\mathrm{MgCl}_{2}$ roasting operation. This was the first 
$\mathrm{MgO}$ roaster system built and operated in the West in approximately thirty years. Figure $4 \mathrm{a}$ shows a 3D model developed during the design of the plant and Figure $4 \mathrm{~b}$ shows the completed unit.

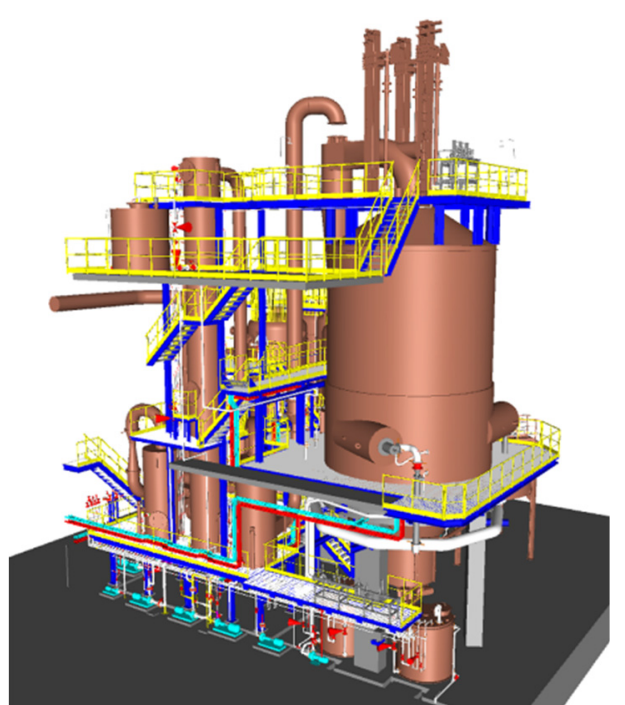

(a)

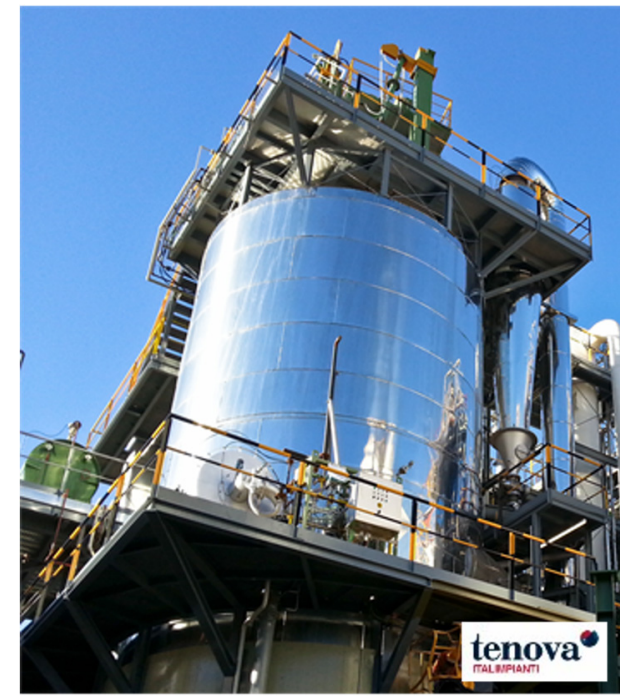

(b)

Figure 4. The Tenova $\mathrm{MgO}$ roaster, with a capacity of $3000 \mathrm{~L} / \mathrm{h}$ of $\mathrm{MgCl}_{2}$ solution: (a) $3 \mathrm{D}$ model developed during the design phase; (b) the completed unit in operation.

\section{Conclusions/Outlook}

The technological concepts for the carbon-neutral production of $\mathrm{MgO}$ are ready for industrial implementation. The preliminary testing of aspects of the concept using ore from the WHY serpentine deposit gave very promising results. The continued development of the concept with WHY in Canada, the evaluation of other non-carbonate magnesia sources, and the further rollout of this technology should lead to the more sustainable production of $\mathrm{MgO}$ in the future.

Author Contributions: Conceptualization, D.K. and G.K.; methodology, D.K.; validation, D.K.; investigation, D.K.; writing—original draft preparation, D.K.; writing—review and editing, G.K.; visualization, D.K. and G.K.; supervision, G.K. All authors have read and agreed to the published version of the manuscript.

Acknowledgments: We are very grateful for the assistance given by West High Yield Resources Ltd. (P.O. Box 68121, Calgary, Alberta, Canada T3G 3N8) in allowing us to use the specific data and results of testing of materials taken from the property under development at Record Ridge. We also wish to acknowledge the help given by the team at Kingston Process Metallurgy Inc. (759 Progress Avenue Kingston, Ontario, Canada K7M 6N6) in executing the practical bench-scale lab tests for WHY, in cooperation with the remote supervision of KON Chem.

Conflicts of Interest: The authors advise that their company offers and distributes the described technology on the world market. The figures and information given have been compiled to the best of their knowledge and belief, but assumptions have also been made based on existing experience. No guarantees or obligations are given by the authors relating to this technological summary.

\section{References}

1. Metallgesellschaft, A. Gewinnung von Magnesiumoxyd aus Wasserhaltigen Magnesiumchloridlösungen Oder Schmelzen; Reichspatentamt: Berlin, Germany, 1935.

2. Grohmann, H.; Grill, M. Method and Apparatus for Large Scale Manufacture of Metal Oxides, Especially Magnesium Oxide; Veitscher Magnesitwerke A.-G.: Vienna, Austria, 1979.

3. Grill, M. Die Fällung von Eisenhydroxid aus Magnesiumchloridlösungen; Institut für Physikalische Chemie; Montanuniversität Leoben: Leoben, Austria, 1983. 
4. Grill, M.; Graf, G. Manufacture of Pure Magnesium Oxide, Especially for the Manufacture of Refractory Products; Veitscher Magnesitwerke A.-G.: Vienna, Austria, 1988.

5. Meier, A. Charakterisierung der Oberfläche Einer Neuen Amorphen Kieselsäure; Institut für Physikalische Chemie; Montanuniversität Leoben: Leoben, Austria, 1989. 